\title{
Seroprevalence of Anti-SARS-CoV- 2 Antibodies among Health Care Workers: Kasr Al Ainy Screening Study
}

\author{
HALA FARAWELA, M.D. ${ }^{\mathbf{1}}$; MAI M. SHERIF, M.D. ${ }^{\mathbf{1}}$; MONA S. HAMDY, M.D. ${ }^{\mathbf{1}}$; HALA SALAH, M.D. ${ }^{\mathbf{2}}$; \\ AHMED A. TAHA, M.D. ${ }^{3}$; REEM J. FARID, M.D. ${ }^{1}$; RANIA H. KHALIFA, M.D. ${ }^{1}$; \\ MARIAM O.F. HANNA, M.D. ${ }^{1}$; DINA M.R. BAHGAT, M.D. ${ }^{1}$; RASHA M.H. SHAHIN, M.D. ${ }^{1}$; \\ HEBA M. SELIM, M.D. ${ }^{1}$; ENGY EL KHATEEB, M.D. ${ }^{1}$; NERMINE M. RIAD, M.D. ${ }^{1}$; \\ FATMA H. ABDELRAOUF, M.D. ${ }^{1}$; HEND H. TAMIM, M.D. ${ }^{1}$; HISHAM EL MINAWI, M.D. ${ }^{4}$ and \\ NOHA M.H. SHAHEEN, M.D. ${ }^{1}$ \\ The Department of Clinical Pathology ${ }^{1}$, Pediatrics Department ${ }^{2}$, Vascular Surgery Department ${ }^{3}$ and Plastic Surgery Department ${ }^{4}$ \\ Faculty of Medicine, Cairo University
}

\begin{abstract}
Background: Egypt is affected by the COVID-19 pandemic in all aspects of life: Health, economy and socially. Serological survey for SARS-CoV-2 antibodies is a valuable method to assess the extent of spread of the pandemic especially in healthcare workers (HCW), and to detect asymptomatic cases.

Aim of Study: This research aims at proving the usefulness of SARS-CoV-2 antibody detection to identify and isolate infected individuals among HCW. Results may be employed as a surrogate to economize the use of RT-PCR evaluation and to make executive decision limiting viral spread among medical personnel in Kasr Al Ainy hospitals.

Material and Methods: This cross-sectional survey study has included $897 \mathrm{HCW}$ from multiple frontline and susceptible services within Kasr Al Ainy, Cairo University Hospitals. $\mathrm{HCW}$ were subjected to wide screening to study the presence of SARS-CoV-2 specific antibody responses (IgG and $\operatorname{IgM}$ ) by Electro-chemiluminescence immunoassay tests and Lateral Flow Immunochromatographic assay (Rapid detection test) kits.
\end{abstract}

Results: Our screening program has revealed 105 positive cases which accounts for $11.7 \%$ of the screened group. Of those, $33(31.4 \%)$ were symptomatic and $72(68.6 \%)$ were asymptomatic.

Conclusion: The use of COVID-19 antibody testing for $\mathrm{HCW}$ can provide crucial information that might prevent further propagation of infection among $\mathrm{HCW}$ and their patients. Further research is warranted to provide evidence related to wide implementation of screening programs for $\mathrm{HCW}$ and to provide clear guidelines related to specifics of such programs.

Key Words: SARS-CoV-2 antibody - Healthcare workers Electro-chemiluminescence immunoassay - Rapid detection test - RT-PCR - Egypt.

Correspondence to: Dr. Hend H. Tamim E-Mail: hend-tamim@hotmail.com

\section{Introduction}

SINCE December 2019, Corona virus disease 2019 (Covid-19), caused by the severe acute respiratory syndrome coronavirus 2 (SARS-CoV-2), rapidly escalated into a world pandemic affecting more than 88 million persons and claiming the lives of more than 1.9 million victims globally [1]. SARSCoV-2 was first detected in Egypt in February 2020 , spreading to reach 146,809 confirmed cases and 8,029 deaths by January 2021 .

Health care workers (HCW) are especially vulnerable to being infected in their working environment, with the fact that access to Personal Protective equipment differs significantly on national and international scales. The infection of $\mathrm{HCW}$ is troubling because they can spread the infection among patients in clinical settings. In addition, loss of work force during this health crisis can lead to reduction of the healthcare system capacity [2]

The molecular testing methods are considered one of the standard methods for diagnosing Covid19 [3]. However, molecular testing is not perfect, requiring certified laboratories, expensive equipment, and trained personnel. More important, the results have the possibility of being false negative; with $93 \%$ positivity rate in bronchoalveolar lavage, $72 \%$ in sputum, $63 \%$ in nasal swab, $46 \%$ in bronchoscope brush biopsy, and $32 \%$ in pharyngeal swab $[3,4]$.

Antibody testing can be considered as an important strategy in the diagnostic toolbox for Covid19 [5-9], being simple, fast, easy in sampling and 
cost-effective thus reducing the pressure on the more expensive molecular testing reserving it to critical patients [3]. Moreover, antibody testing complements molecular testing for the diagnosis of suspected cases with negative molecular testing results. It is also important in surveying for asymptomatic infection in close contacts [10].

Gaining experience in managing resources and protecting $\mathrm{HCW}$ would be extremely valuable not only in epidemiological context but for potential use of antibody testing on larger scales [11,12]

Our work aimed at proving the usefulness of SARS COV2 antibody detection to identify and isolate infected individuals among $\mathrm{HCW}$ and to use results as surrogate to economize the use of RT-PCR evaluation and to make executive decision to limit the viral spread among medical personnel working in an academic center of excellence.

\section{Material and Methods}

Study design:

This cross-sectional study has included 897 $\mathrm{HCW}$ in multiple facilities of Kasr Al Ainy Cairo University Hospitals, Egypt. The study protocol was approved by the institutional ethical committee (according to the WMA Declaration of Helsinki).

All HCW recruited signed an informed consent form. They also answered a questionnaire to provide demographic data; clinical information related to known risk factors as well as multiple health indices and certain key symptoms and signs. A single blood sample of $5 \mathrm{ml}$ was drawn in sterile vacutainer. All HCW were tested using both Electro-chemiluminescence immunoassay and Lateral Flow Immunochromatographic assay (Rapid detection test) (RDT) kits and tests were performed under strict biosafety conditions.

Serological testing for SARS-Cov-2 specific antibodies by:

1- Elecsys ${ }^{\circledR}$ (Roche diagnostics, Switzerland) Anti SARS CoV 2 immunoassay intended for qualitative detection of antibodies to SARS CoV 2 in human serum and plasma (according to manufacturer's instructions). This technique is associated with sensitivity of $65.5 \%$ (0-6 days); of $88.1 \%$ (713 days); $100 \%$, and $99.81 \%$ specificity (14 days onwards) [13] .

2- Artron ${ }^{\circledR}$ Laboratories Inc. (BC, Canada) one step Covid-19 IgM/IgG antibody test: (According to manufacturer's instructions). Detection of IgM and IgG antibodies for SARS-CoV2 was performed using the One Step Novel Coronavirus (Covid-19) IgM/IgG Antibody Test (Artron, Burnaby, Canada).
The test is associated with $93.4 \%$ sensitivity and $97.7 \%$ specificity [13]

\section{Statistical analysis:}

Continuous variables were expressed as the mean \pm standard deviation (SD) categorical variables were described as the count (\%). All analyses were done with SPSS Statistics software (version 23.0). A two-sided $p$-value of less than 0.05 was considered statistically significant. Comparison of numerical variables was done using unpaired $t$ test. For comparing categorical data, chi square test was performed.

\section{Results}

Demographic data, risk factors and clinical manifestations of the study group are shown in Table (1).

The screening program of serological testing of $897 \mathrm{HCW}$ has revealed that $105(11.7 \%) \mathrm{HCW}$ were positive for virus-specific antibodies while the remaining $792(88.3 \%)$ were negative. Comparison between the positive and negative SARSCoV-2 specific antibodies HCW groups regarding demographic data, risk factors and clinical manifestations revealed statistically significant difference concerning; age ( $p$-value $=0.045)$, fever $(p$ value $=0.011)$, dyspnea $(p$-value $<0.001)$, cough $(p$-value $=0.009)$, and diabetes $(p$-value $=0.035)$ (Table 2 ). The vast majority of the positive group were asymptomatic $72(68.6 \%)$ while the rest 33 $(31.4 \%)$ reported at least one of the following symptoms, namely dyspnea, cough or fever.

Among the positive $105 \mathrm{HCW}$; 64 (61\%) were positive for virus specific antibodies by both Electro-chemiluminescence immunoassay and RDT techniques, $39(37.1 \%)$ cases had positive virus specific antibodies with RDT only while testing negative with Electro-chemiluminescence immunoassay. Only two cases $(1.9 \%)$ tested positive with Electro-chemiluminescence immunoassay while providing negative results with RDT. Regarding the positive HCW screened by RDT, 52 (50.5\%) had positive IgM antibodies only, 13 $(12.6 \%)$ had positive IgG antibodies only while $38(36.9 \%)$ tested positive for both IgG and IgM.

Patients who tested positive with serological tests were referred to the infection control unit. They were advised to self-isolate and RT-PCR testing was proposed. 85 subjects out of the 105 who tested positive accepted to undergo RT-PCR. Among those 85 SARS Cov2 specific antibodies positive cases; 44 (51.8\%) tested positive and 41 (48.2\%) tested negative with RT-PCR. 
Table (1): Demographic data, risk factors and clinical manifestations.

\begin{tabular}{lc}
\hline Characteristics & Study group (n 897) \\
\hline Age (years) & $38.7 \pm 11.3$ \\
Males & $387(43.14 \%)$ \\
Diabetes & $81(9.0 \%)$ \\
Hypertension & $118(13.1 \%)$ \\
Obesity & $100(11.1 \%)$ \\
Asthma & $57(6.3 \%)$ \\
Fever & $80(8.9 \%)$ \\
Cough & $140(15.6 \%)$ \\
Dyspnea & $85(9.4 \%)$ \\
\hline
\end{tabular}

Table (2): Comparison of the demographic data, risk factors and clinical manifestations between the positive and negative SARS-CoV-2 specific antibodies HCW groups.

\begin{tabular}{|c|c|c|c|}
\hline & $\begin{array}{l}\text { Positive group } \\
\quad \text { (n 105) }\end{array}$ & $\begin{array}{l}\text { Negative group } \\
\quad(\mathrm{n} 792)\end{array}$ & $\begin{array}{c}p- \\
\text { value }\end{array}$ \\
\hline \multicolumn{4}{|l|}{ Sex: } \\
\hline Male & $40(38.1 \%)$ & $347(43.8 \%)$ & 0.223 \\
\hline Female & $65(61.9 \%)$ & $44556.2 \%)$ & \\
\hline Age $($ Mean \pm SD) & $41.01 \pm 11.02$ & $38.57 \pm 10.95$ & 0.045 \\
\hline Diabetes & $17(16.2 \%)$ & $72(9.1 \%)$ & 0.035 \\
\hline Hypertension & $19(18.1 \%)$ & $110(13.9 \%)$ & 0.271 \\
\hline Obesity & $19(18.1 \%)$ & $90(11.4 \%)$ & 0.06 \\
\hline Fever & $18(17.1 \%)$ & $70(8.8 \%)$ & 0.011 \\
\hline Sore throat & $32(30.5 \%)$ & $215(27.1 \%)$ & 0.139 \\
\hline Cough & $28(26.7 \%)$ & $125(15.8 \%)$ & 0.009 \\
\hline Dyspnea & $23(21.9 \%)$ & $71(8.9 \%)$ & $<0.001$ \\
\hline
\end{tabular}

$p<0.05$ is statistically significant.

\section{Discussion}

Healthcare workers always play a critical role not only in the clinical management of patients but also in maintaining adequate infection prevention and control measures in health care facilities [14]. The main way to limit spread of the virus is to rapidly diagnose disease, isolate infected personnel and maintain contact tracing methods $[\mathbf{1 5 , 1 6 ]}$ Serological assays are now being developed as a screening tool for population based serosurveys and detection of past infection [17].

In this study, $105(11.7 \%)$ of the 897 screened $\mathrm{HCW}$ tested positive for SARS-CoV-2 specific antibodies. Of those, 33 (31.4\%) were symptomatic and $72(68.6 \%)$ were asymptomatic. This agrees with multiple published reports that have concluded that the numbers of asymptomatic Covid-19 cases are significant and ranges from $51.7 \%$ in one report, to $87.9 \%$ in another. The advantage of detecting such cases is clear, asymptomatic subjects seem to account for a significant percentage of SARS$\mathrm{CoV}-2$ infections, approximately half of patients according to published reports [18-28].
On the other hand, in a study by Khalil et al., [29], $266 \mathrm{HCW}$ were tested using RT-PCR and $18 \%$ were found to be positive; of these $66 \%$ were symptomatic and $34 \%$ were asymptomatic. Hunter et al., [2], screened symptomatic HCW in their establishment, also using RT-PCR, and reported $14 \%$ positives out of 244 screened subjects. Worthy of note, that in our study we offered our screening program to most frontline subjects without specifically targeting symptomatic cases.

RT-PCR assay is one of the standard methods in diagnosing SARS-CoV-2. The method nevertheless has a relatively high percentage of falsenegative results. This can be due to issues inherent to the method, to sample collection and transportation among other things [30].

Testing for antibodies to screen subjects has obvious advantages over RT-PCR [31,32] . The tests do not require highly trained individuals to perform, do not need expertise in reading results, do not require sophisticated and expensive equipment and can be performed in a significantly shorter period [11]. Blood samples for antibody testing are significantly more accessible than nasopharyngeal swabs, which would inherently offer a clear advantage. For all these reasons we have chosen to employ the antibody screening strategy for our HCW.

In addition to such clear advantages, some cases that are detected by antibody screening may test negative with RT-PCR. This could be due to errors related to sampling and transport or could simply be time sensitive, where RT-PCR has been performed in a period within the natural history of the disease that corresponds to high potential of negativity. This in essence denotes that RT-PCR and serological testing can be complementary and that their potential value depends on the period of testing after onset of symptoms.

In this study, 41 out of 85 (48.2\%) HCW tested positive for SARS-Cov-2 Abs but showed negative results by RT-PCR this is in accordance with a study by Long et al., [10], where 164 close contacts of patients of Covid-19 were screened, out of those 13 symptomatic individuals were confirmed positive for the disease by RT-PCR. 3 other asymptomatic individuals were confirmed positive by RTPCR. 148 individuals were both asymptomatic and tested negative with RT-PCR, out of those 7 were found to have virus specific IgG and/or IgM. They thus noted that $4.3 \%$ of close contacts were missed with RT-PCR. They concluded that the role of serological testing is important in estimating the extent of the disease pandemic in certain populations. 
It is worthy of note that in one published report, RNA detectability decreased from $66.7 \%$ in samples collected before day 7 to $45.5 \%$ during day 15-39, while the presence of antibodies was $<40 \%$ among patients within 1-week since onset, and rapidly increased to $100.0 \%$ (Total $\mathrm{Ab}$ ), $94.3 \%$ (IgM), and $79.8 \%$ (IgG) 15 days after onset of symptoms [3]

In an ideal situation, a screening program should include both RT-PCR and antibody testing. This is because different methodologies are sensitive in different time periods during the disease progression and taking in consideration that screening programs specifically strives to detect asymptomatic cases, it goes without saying that employing multiple screening tools would increase the efficiency of such programs.

Our screening strategy detects the presence of SARS-CoV-2 specific antibody responses (IgG and IgM) by Electro-chemiluminescence immunoassay tests and RDT kits. This goes with the recommendations of the Centers for Disease Control and Prevention (CDC) (the Interim Guidelines for Covid-19 Antibody Testing Updated in Aug. $1,2020)$ which suggested that to improve positive predictive value of the testing strategies, persons who initially tested positive are to be tested with a second test, each with unique design characteristics.

In sight of the above mentioned, the attention should be drawn to the pivotal role of screening programs of HCW. Detecting and isolating asymptomatic HCW, the majority of positive cases in our series, should reduce significantly viral spread among HCW and among their highly susceptible patients. This has the potential to maintain more numbers of HCW within the workforce, and potentially reduces the disease severity of infected cases, as care would be offered at an earlier stage, and reduces overall disease burden in the community.

Reducing transmission is of paramount importance in situations where necessary equipment might be in dire need. Multiple studies have also mentioned that such screening programs provide psychological and moral support to $\mathrm{HCW}$, who feel that their leadership is taking their welfare seriously.

Refining the understanding of how to employ antibody screening for $\mathrm{HCW}$, would also potentially offer us a pragmatic tool by which HCW would be repeatedly screened during the peak period of the pandemic, to give us a better measure of our success in employing infection control strategies [33].

\section{Conclusion:}

We should not ignore the fact that we are facing a pandemic that gripped the world vigorously. Our work draws the attention to the importance of screening programs for $\mathrm{HCW}$ as an indispensable tool in limiting viral propagation. To perfect screening programs and refine tools to augment their value, further longitudinal trials seem to be essential. Researchers around the world are developing vaccines against SARS-CoV-2 but many concerns have emerged concerning antibody testing regarding the recommendation to get antibody test before and/or after receiving the vaccine and the necessity of vaccination in presence of a high antibody titer. All these inquiries are opening the field to many upcoming research involving antibody testing.

\section{Declarations:}

\section{- Ethics approval and consent to participate:}

This study was performed in line with the principles of the Declaration of Helsinki. Approval was granted by the Ethics Committee of Cairo University, Cairo, Egypt. All participants signed a written informed consent.

\section{- Competing interests:}

The authors declare that they have no competing interests.

\section{- Authors' contributions:}

HF provided administrative and supervisory support, participated in the design and revision of the manuscript; MMS participated in the design, in the acquisition, analysis and interpretation of the data; MSH participated in the acquisition, analysis and interpretation of the data; HS and AAT provided administrative support; RJF, RHK, MOFH, HMS and FHA participated in the acquisition, analysis and interpretation of the data; DMRB, RMHS, EEK and NMR participated in the acquisition, analysis, interpretation of the data and in revision of the manuscript; HHT participated in the acquisition, analysis, interpretation of the data and is the corresponding author; HEM provided administrative support; NMHS participated in the design, in the acquisition, analysis, interpretation of the data, wrote and revised the manuscript. All authors read and approved the final manuscript.

\section{-Acknowledgments:}

We thank Prof. Dr. Tarek Shaarawy. Professor of Ophthalmology, Geneva University Hospitals, Geneva, Switzerland, who provided insight and expertise that greatly assisted the research. 


\section{References}

1- ZHENG J.: SARS-CoV-2: An Emerging Coronavirus that Causes a Global Threat. Int. J. Biol. Sci., 16 (10): 16781685. doi: 10.7150/ijbs.45053, 2020.

2- HUNTER E., PRICE D.A., MURPHY E., VAN DER LOEFF I. S., BAKER K.F., LENDREM D., et al.: First experience of COVID-19 screening of health-care workers in England. Lancet, 395 (10234): e77-e8. doi: 10.1016/ S0140-6736(20)30970-3, 2020.

3- JACOFSKY D., JACOFSKY E.M. and JACOFSKY M.: Understanding Antibody Testing for COVID-19. J. Arthroplasty, 35(7):S74-S81. doi: 10.1016/j.arth.2020.04.055, 2020.

4- WANG W., XU Y., GAO R., LU R., HAN K., WU G., et al.: Detection of SARS-CoV-2 in Different Types of Clinical Specimens. Jama, 323 (18): 1843-1844. doi: 10.1001/jama.2020.3786, 2020.

5- ZULLO F., DI MASCIO D. and SACCONE G.: COVID19 Antibody Testing in Pregnancy. Am. J. Obstet. Gynecol. MFM, 100142. doi: 10.1016/j.ajogmf.2020.100142, 2020.

6- XIE J., DING C., LI J., WANG Y., GUO H., LU Z., et al.: Characteristics of patients with coronavirus disease (COVID-19) confirmed using an IgM-IgG antibody test. J. Med. Virol., 92 (10): 2004-2010. doi: 10.1002/jmv. 25930, 2020.

7- WU Y., LI C., XIA S., TIAN X., KONG Y., WANG Z., et al.: Identification of Human Single-Domain Antibodies against SARS-CoV-2. Cell Host Microbe, 27 (6): 891898.e5. doi: 10.1016/j.chom.2020.04.023, 2020.

8- WEINSTEIN M.C., FREEDBERG K.A., HYLE E.P. and PALTIEL A.D.: Waiting for Certainty on Covid-19 Antibody Tests - At What Cost? N. Engl. J. Med., 383: e37. doi: 10.1056/NEJMp2017739, 2020.

9- VAN ELSLANDE J., HOUBEN E., DEPYPERE M., BRACKENIER A., DESMET S., ANDRÉ E., et al.: Diagnostic performance of seven rapid IgG/IgM antibody tests and the Euroimmun IgA/IgG ELISA in COVID-19 patients. Clin. Microbiol. Infect, 26 (8): 1082-1087. doi: 10.1016/j.cmi.2020.05.023, 2020.

10- LONG Q.X., LIU B.Z., DENG H.J., WU G.C., DENG K., CHEN Y.K., et al.: Antibody responses to SARS-CoV2 in patients with COVID-19. Nat. Med., 26: 845-848. doi: 10.1038/s41591-020-0897-1, 2020.

11- RONGQING Z., LI M., SONG H., CHEN J., REN W., FENG Y., et al.: Early Detection of Severe Acute Respiratory Syndrome Coronavirus 2 Antibodies as a Serologic Marker of Infection in Patients With Coronavirus Disease 2019. Clin. Infect Dis. Nov. 19; 71 (16): 2066-2072. doi: 10.1093/cid/ciaa523, 2020.

12- GODLEE F.: The burning building. BMJ, 368, 2020.

13- GRONVALL G., CONNELL N., KOBOKOVICH A., WEST R., WARMBROD K.L., SHEARER M.P., et al.: Developing a National Strategy for Serology (Antibody Testing) in the United States: The Johns Hopkins Center for Health Security; [Available from: http://www. centerforhealthsecurity.org/resources/COVID-19/serology/ Serology-based-tests-for-COVID-19.html], 2020.

14- Protocol for assessment of potential risk factors for coronavirus disease 2019 (COVID-19) among health workers in a health care setting, [https://www.who.int/ emergencies/diseases/novel-coronavirus-2019/technicalguidance/early-investigations], 2020.

15-TANG Y.W., SCHMITZ J.E., PERSING D.H. and STRATTON C.W.: The laboratory diagnosis of COVID-19 infection: Current issues and challenges. J. Clin. Microbiol., 58 (6): e00512-520. doi: 10.1128/JCM.00512-20, 2020.

16- HANSON K.E., AZAR M.M., BANERJEE R., CHOU A., COLGROVE R.C., GINOCCHIO C.C., et al.: Infectious Diseases Society of America guidelines on the diagnosis of COVID-19. IDSA, ciaa760. doi: 10.1093/ $\mathrm{cid} /$ ciaa760. [Epub ahead of print], 2020.

17- JÄÄSKELÄINEN A.J., KEKÄLÄINEN E., KALLIOKOKKO H., MANNONEN L., KORTELA E., VAPALAHTI O., et al.: Evaluation of commercial and automated SARS-CoV-2 IgG and IgA ELISAs using coronavirus disease (COVID-19) patient samples. Euro Surveill, 25 (18): 2000603. doi: 10.2807/1560-7917.ES.2020.25. $18.2000603,2020$.

18- HU Z., SONG C., XU C., JIN G., CHEN Y., XU X., et al.: Clinical characteristics of 24 asymptomatic infections with COVID-19 screened among close contacts in Nanjing, China. Sci. China Life Sci., 63 (5): 706-711. doi: 10.1007/s11427-020-1661-4, 2020.

19- ZHANG H.J., SU Y.Y., XU S.L., CHEN G.Q., LI C.C., JIANG R.J., et al. Asymptomatic and symptomatic SARSCoV-2 infections in close contacts of COVID-19 patients: a seroepidemiological study. Clin. Infect Dis, ciaa771. doi: 10. 1093/cid/ciaa77 1. [Epub ahead of print], 2020

20- WU Z. and McGOOGAN J.M.: Asymptomatic and PreSymptomatic COVID-19 in China. Infect Dis. Poverty, 9 (1): 72. doi: 10.1186/s40249-020-00679-2, 2020.

21- WEI L., LIN J., DUAN X., HUANG W., LU X., ZHOU J., et al.: Asymptomatic COVID-19 Patients Can Contaminate Their Surroundings: An Environment Sampling Study. mSphere, 5(3): e00442- 20. doi: 10. 1 128/mSphere. 00442-20, 2020.

22- VERMUND S.H. and PITZER V.E.: Asymptomatic transmission and the infection fatality risk for COVID-19: Implications for school reopening. Clin. Infect. Dis., ciaa855. doi: 10.1093/cid/ciaa855 [Epub ahead of print], 2020

23- PATEL M.C., CHAISSON L.H., BORGETTI S., BURDSALL D., CHUGH R.K., HOFF C.R., et al.: Asymptomatic SARS-CoV-2 infection and COVID-19 mortality during an outbreak investigation in a skilled nursing facility. Clin. Infect. Dis., Ciaa763. doi: 10.1093/cid/ciaa763 [Epub ahead of print], 2020.

24- NOH J.Y., YOON J.G., SEONG H., CHOI W.S., SOHN J.W., CHEONG H.J., et al.: Asymptomatic infection and atypical manifestations of COVID-19: Comparison of viral shedding duration. J. Infect., 81 (5): 816-846. doi: 10.1016/j.jinf.2020.05.035, 2020.

25- KRONBICHLER A., KRESSE D., YOON S., LEE K.H., EFFENBERGER M. and SHIN J.I.: Asymptomatic patients as a source of COVID-19 infections: A systematic review and meta-analysis. Int. J. Infect. Dis., 98:180-186. doi: 10.1016/j.ijid.2020.06.052, 2020.

26- HUFF H.V. and SINGH A.: Asymptomatic transmission during the COVID-19 pandemic and implications for public health strategies. Clin. Infect. Dis., Ciaa654. doi: 10.1093/cid/ciaa654 [Epub ahead of print], 2020. 
27- GOLDBERG S.A., PU C.T., THOMPSON R.W., MARK E., SEQUIST T.D. and GRABOWSKI D.C.: Asymptomatic Spread of COVID-19 in 97 Patients at a Skilled Nursing Facility. J. Am. Med. Dir. Assoc., 980-981. doi: 10.1016/j.jamda.2020.05.040, 2020.

28- BORRAS-BERMEJO B., MARTINEZ-GOMEZ X., SAN MIGUEL M.G., ESPERALBA J., ANTÓN A., MARTIN E., et al.: Asymptomatic SARS-CoV-2 Infection in Nursing Homes, Barcelona, Spain, April 2020. Emerg. Infect. Dis., 26 (9): 2281-3. doi: 10.3201/eid2609.202603, 2020.

29- KHALIL A., HILL R., LADHANI S., PATTISSON K. and O'BRIEN P.: COVID-19 screening of health-care workers in a London maternity hospital. Lancet Infect. Dis., S1473-3099(20)30403-5. doi: 10.1016/S14733099(20)30403-5, 2020

30- YANG H.S., RACINE-BRZOSTEK S.E., LEE W.T., HUNT D., YEE J., CHEN Z., et al.: SARS-CoV-2 antibody characterization in emergency department, hospitalized and convalescent patients by two semi-quantitative im- munoassays. Clin. Chim. Acta., 509:117-125. doi: 10.1016/j.cca.2020.06.004, 2020.

31- STRINGHINI S., WISNIAK A., PIUMATTI G., AZMAN A.S., LAUER S.A., BAYSSON H., et al.: Seroprevalence of anti-SARS-CoV-2 IgG antibodies in Geneva, Switzerland (SERO CoV-POP): A population-based study. Lancet, 396 (10247): 313-319. doi: 10.1016/S0140-6736(20) 31304-0, 2020.

32- UDUGAMA B., KADHIRESAN P., KOZLOWSKI H.N., MALEKJAHANI A., OSBORNE M., LI V.Y.C., et al.: Diagnosing COVID-19: The Disease and Tools for Detection. ACS Nano, 14 (4): 3822-3835. doi: 10.1021/ acsnano.0c02624, 2020.

33- RICCO M., FERRARO P., GUALERZI G., RANZIERI S., HENRY B.M., SAID Y.B., et al.: Point-of-Care Diagnostic Tests for Detecting SARS-CoV-2 Antibodies: A Systematic Review and Meta-Analysis of Real-World Data. J. Clin. Med., 9 (5): 1515. doi: 10.3390/jcm9051515, 2020.

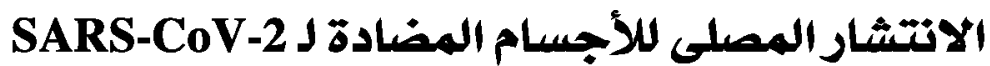

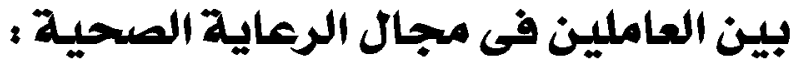 دراسة فحص بالقصر فال العينى}

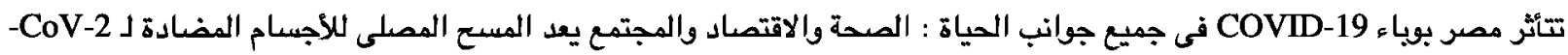
طريقة قيمة لتقييم مدى انتشار الوباء خاصة فى العاملين فى مجال الرعاية الصحية، واكثشاف الصالات التى لا تظهر عليها أعراض.

يهدف هذا البحث إلى إثبات فائدة اكتثاف الأجسام المضادة لـ SARS-CoV-2 لتصديد وعزل الأفراد المصابين بين العاملين فى مجال

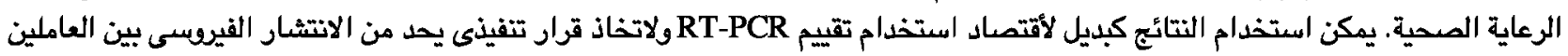

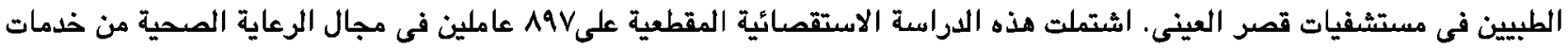

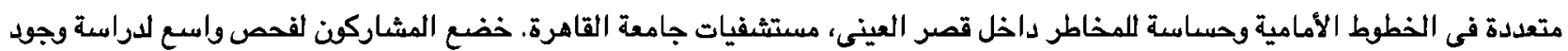

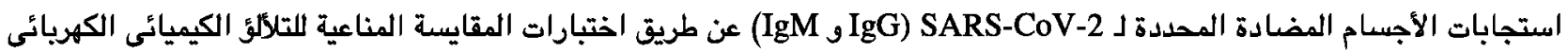

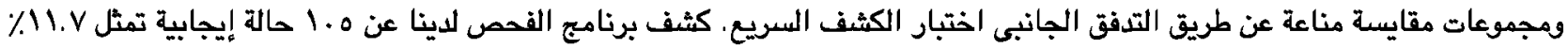

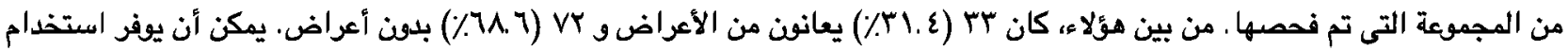

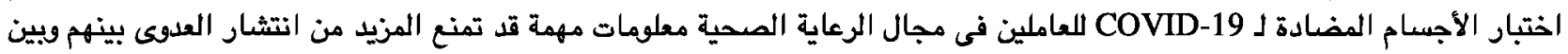

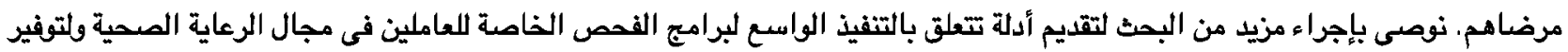
إرشادات واضحة تتعلق بتفاصيل هذه البرامج مرئ. 